\title{
Environmental Biopollutants inside Gunj Vegetable Market Nizamabad
}

Prasannarani Tanneru*

Department of Botany, Lal bahadur Shastri Mahavidyalaya, Dharmabad, Dist Nanded, Maharashtra, India

DOI: $10.36347 / \mathrm{sajb} .2020 . v 08 i 03.004$

| Received: 09.03.2020 | Accepted: 20.03.2020| Published: 30.03 .2020

*Corresponding author: Prasannarani Tanneru

\section{Abstract}

Original Research Article

Airmonitoring over the vegetable market was undertaken by using Burkard air sampler and petriplate exposure method. Preliminary investigation with the help of Burkard air sampler indicates very high concentration of Aspergillus (34.10\%) in Sept. 2019 and (42.80\%) in Oct. 2019. Petriplate exposure method also indicates similar type of observation in addition to Aspergillus type. Several other types were also encountered which have been identified. The relevance of the concentration of spore types and meteorological parameters has been brought out. The influence on the visitors due to the release of pathogenic forms of the vegetable market is also in consideration and detailed results will be presented in due course.

Keywords: Biopollutants Gunj Vegetable Market Airmonitoring Petriplate Aspergillus.

Copyright @ 2020: This is an open-access article distributed under the terms of the Creative Commons Attribution license which permits unrestricted use, distribution, and reproduction in any medium for non-commercial use (NonCommercial, or CC-BY-NC) provided the original author and source are credited

\section{INTRODUCTION}

Airborne models have been found to be responsible for biodegradation of vegetables and fruits in market area. Many of the microbial forms of the aeromicrobioata are hazardous to plants animals and human beings. The influence of meteorological parameters like temperature, humidity rainfall and wind velocity also play important role. The fungi growing on vegetables/fruits in the market form the sources of spores where they grow as saprophytes or parasites. There is a direct relationship between the occurrence of market diseases of vegetables and aeromicroflora of the particular market.

Sullia and Khan [1], and Singh and Misra [2] have studied aeromycoflora of the different vegetable market atmospheres and stated that a relationship exists between the occurrence of market diseases of vegetables/fruits and aeromycoflora of the particular market. There is also possibility of release of spores in the market environment during storage and transit. The aerospora of market may also have some implications on the health of the people working in the market and the visitors.

\section{MATERIAL AND METHODS}

Aerobiological survey was carried out inside Gunj Vegetable Market, Nizamabad, and Telangana from Sept 2019-Nov 2019. Fungal spores were sampled fortnightly by Andersen sampler i.e. exposure of petridishes containing agar media in the open air for 5 and 10 minutes and by operating Burkard air sampler for ten minutes. Slides were prepared and scanned and number of spores $/ \mathrm{m}^{3}$ of air was calculated. During the sampling, sampler was kept at a constant height to 3 feet.

\section{RESULTS AND DISCUSSION}

Both Burkard air sampler and Andersen sampler were used simultaneously. The samplers provide both qualitative and quantitative data of aeromicrobiodata, large numbers of spore counts were recorded during the study period. The results of scanning shows a total 40 identified fungal spore types. The relative contribution of the fungal group of the total airspora shows 2 Phycomycotina, 7 type of Ascomycotina, 3 types of Basidiomycotina and the remaining of Deuteromycotina. The other type includes unidentified spores, insect scales, protozoan cysts, algal filaments, etc. The class Deuteromycotina contributes $86.6 \%$ to the total airspora, Aspergillus was the dominant spora type throughout the period of investigation. The Aspergilli contributed (36.2\%) to the total airspora.

The second dominant type was Cladosporium (23.19\%) followed by Alternaria curvularia (*.61\%). Helminthosporium (5.09\%). Nigrospora (2.10\%), Smuts $(1.32 \%)$ and Dreschhlara (1.59\%). The results of petriplate exposure shows the dominance of Aspergillus niger $(10.02 \%)$ and Aspergillus flavus $(8.10 \%)$ followed by Aspergillus fumigates (4.58\%). Aspergillus candidus 
(2.20\%) Aspergillus nidulans (1.74\%) and Aspergillus sydowii $(1.22 \%)$

The highest concentration of Aspergillus sps. was observed in the month of Oct. (42.8\%). The favourable meteorological factors such as mean humidity, $(80.3 \%)$ mean rainfall $(4.19 \%)$ mean temperature $(19.7 \%)$ plays an important role in the growth of fungal spores.

Conclusively, the working environment like market place with microbial contamination or biopollutants may be a major health problem. Biodegradation of stored products and other organic materials have been subjected to large number of airborne spores when they are transported.

It has been known that inhalation of mild spores can produces allergic respiratory symptoms [3, 4]. It is believed that a relationship exists between the occurrence of market diseases and the airspora of particular market [1]. The adverse effects of inhaled fungal spores causes disorders like rhinitis, asthama and bronchial disorders.

Table-1: Monthly variation in percentage contribution of various groups in Gunj Vegetable Market Environment

\begin{tabular}{|c|c|c|c|}
\hline Groups & September & October & November \\
\hline Phycomycotina & 13.47 & 7.78 & 5.19 \\
\hline Ascomycotina & 1.6 & 1.51 & 1.48 \\
\hline Deuteromycotina & 83.33 & 88.55 & 9.12 \\
\hline Other types & 1.60 & 2.16 & 3.21 \\
\hline
\end{tabular}

Table-2: Percentage contribution of major fungal types trapped by Burkard Sampler from the Air of Gunj

\begin{tabular}{|l|c|c|c|}
\hline vegeable Market \\
\hline Spore type & September & October & November \\
\hline Smuts & 1.02 & 1.27 & 1.62 \\
\hline Aspergilli & 1.2 & 14.00 & 9.78 \\
\hline Cercospora & 34.80 & 42.80 & 31.02 \\
\hline Cladosporium & 0.82 & 1.20 & 0.38 \\
\hline Curvularia & 20.08 & 26.90 & 22.60 \\
\hline Drechslera & 5.02 & 12.87 & 7.96 \\
\hline Fusarium & 1.82 & 1.99 & 0.98 \\
\hline Helminthosporium & 2.00 & 3.02 & 1.28 \\
\hline Nigrospora & 6.02 & 4.80 & 4.45 \\
\hline Hyphal Fragm & 2.10 & 1.78 & 2.43 \\
\hline Other types & 6.21 & 1.82 & 0.98 \\
\hline
\end{tabular}

\section{REFERENCES}

1. Khan KR, Sullia SB. Arthrinium phaeospermum var. indicum var. nov., a new market pathogen of cowpea, garden pea and French bean. Acta Botanica Indica. 1980;8(1):103-4.

2. Singh SP, Misra N, Dixit KS, Singh N, Kohli RP. An experimental study of analgesic activity of
Cissus quadrangularis. Indian Journal of Pharmacology. 1984 Jul 1;16(3):162.

3. Gravesen S. Fungi as a cause of allergic disease. Allergy. 1979 Jun;34(3):135-54.

4. Salvaggio J, Aukrust L. Mold-induced asthma. Journal of Allergy and Clinical Immunology. 1981 Nov 1;68(5):327-46. 